Vol. 8, Issue 8, August 2021

DOI: $10.17148 /$ IARJSET.2021.8849

\title{
A Study of the Kanjera Instrument and its Significance
}

\author{
Muppidi Rambabu ${ }^{1}$, Ketha Santhi ${ }^{2}$, Chintha Ravi kumar ${ }^{3}$, Manchuri Tulasi ${ }^{4}$ \\ ${ }^{1,2}$ Dr. YSR. Architecture and Fine Arts University, Andhra Pradesh. \\ ${ }^{3}$ Academic Consultant, Dr. YSR. Architecture and Fine Arts University, Andhra Pradesh.
}

\begin{abstract}
There are many such artists in our Andhra Pradesh region who are passionate about the rural world and folklore And the fact that rural folk artists are not only a source of livelihood but also a source of livelihood for many thousands of families who depend on this dream for their name and for the beloved life. Kanjera artist is obscured by the fact that the art is a gift of love and affection so that this art can be proposed on to future generations. rural folklore and to write about the uniqueness of this kanjer livelihood in these families. Village word and folklore have no end in sight to this single eye but this art of the present is very difficult in the present circumstances so the significance of this art is the uniqueness of the important highlights in this art I will tell you through my paper revolves around the Kanjera method of preparation, the community; other crafts from the community ways to revive, recognition from the government and its intervention which will Kanjera elevate the status of this rural craft.
\end{abstract}

Keywords— Folk, Rural art, Culture, Music, Instrument, livelihood

INTRODUCTION : The minds of the villagers are so good for purity so many names are so good for cam ponds legaduda runs If all this is not to say that the world is different the same pond do not know nowadays children no recognized. Folk songs (in Telugu) Koyilamma songs, many other Telugu songs on Palleturu Palleturu Komma Looking at himself and holding a small hen in his hand you can make me feel a little tired This song called Folk is very tired for farm workers gives so much pleasure so this folk is enjoyable Folk artists L.R. Krishna Babu, he is also president of folk artists association of Andhra Pradesh. Such songs that he has sung in history, many people have been impressed by these folk songs. Also in many exhibitions from state level to national level in this exhibition. This is the protagonist who seldom survives and sings his songs through an instrument called kanjera. This kanjara instrument took the bell with me and taught us many instruments to many artists. Apart from this, by giving these kanjera instruments to many government schemes, welfare schemes have been able to create a lot of awareness among the people through songs in the form of songs and costumes. Apart from Kanjara Katha, Burrakatha, Dimsa Natyam is also very proficient in Veeranatyam, Bhamakalapam Kolatam etc. Let's learn about 'Palle Suddulu in his words: The play 'Palle Suddulu' was performed in Kadapa for 7 days by a charity called Palle Siddhu. The play 'Palle Siddhu' was performed in all parts of the Telugu states. Most of the folk songs were sung by Andhra fisher man, Palle Suddulu from here to Delhi Bopal, Gujarat ,Baroda Tana Mahasabha in America. Let's learn about 'Kolatam" in his words. Many students in Kolatam go to private and public schools and wait for about two hours a day of the week as part of their cultural activities.

OBJECTIVE: The main objective of the case study in

- $\quad$ To understand the demographic profile of the Andhra Pradesh Kanjera handicraft product

- $\quad$ To study the second generation folk artist L.R. Krishnababu

- $\quad$ and his achievements

- To The same is true of recognizing families who are living on the folk arts and giving them appropriate encouragement

History: The Middle East History of kanjera in: The 3000years the Middle East Frame Drums? Let's learn about the Middle East Machine One of the oldest such musicalinstruments is three thousand years ago. Ancient sources indicate that the god David and his god were represented in installments in $970-220$ BC. Women around the world are now more likely than men to play frame drums in the form of art exhibitions, films, according to the Epigraphs. Mesopotamia History of Kanjera : What we need to know from the Mesopotamian civilization is that the men and 


\section{DOI: 10.17148/IARJSET.2021.8849}

women who play these instruments worship idols, play their drums, dance, worship God, and have been showing their culture ever since. C.3000 B.C.E- 2000B.C.E. the tribal's used drums to hunt animals and also to protect them. Thus the Middle East Frame drum quote is a testament to the fact that they have had good concerts with voice in the form of installments since that time in their own hands to have music festivals and religious ceremonies. Middle East: These instruments have been identified by historians not only in our country but also in Western countries such as Arabia and western Deoria, Syria, Iraq, and Turkey. Middle East Arabia and South Africa c101 - 202B.C.E. these have been identified.

\section{MAKING PROCESS:}

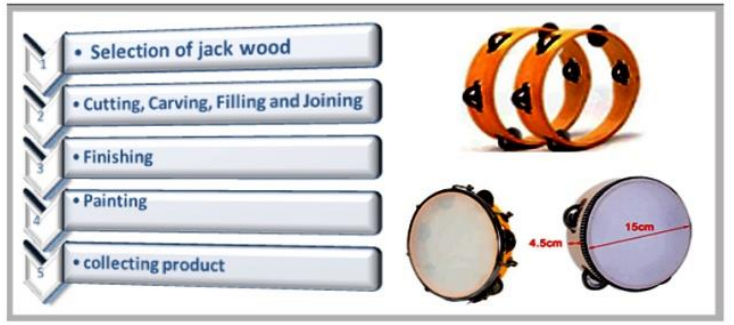

Flow chart and Construction of Kanjera (9 x $7 \times 2$ Inches). ${ }^{16}$
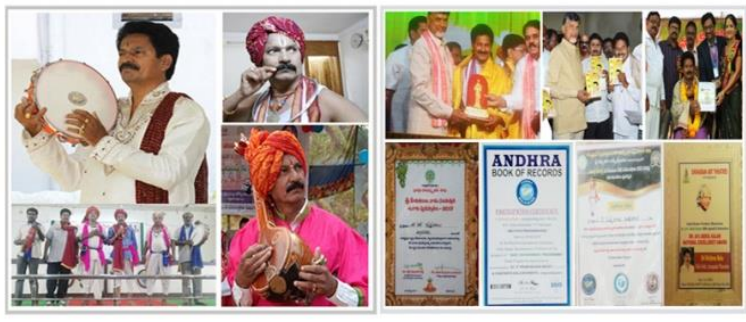

2017 Ugadi Awards Folk song Kanjera Folk Artisan ${ }^{17}$

Ply of Kanjera: Let me know how to play success the kanjera instrument was once a common sight in South India in this the instrument was found on the wall in every house. However the noise is likely to be caused by applying pressure near the outer edge of the fingers of the beaten to left hand. In doing so the beaten hand fingers with the voice of pitch as well as the right hand coming from outside gives the sound of being accompanied by good children This music is very listenable instrument based on such artists it is based, In this way, when the farmer gets tired of playing these kanjera instruments, he can also protect his crop with such instruments. Many of the things that the farmer does with his voice to protect the crop with his voice in order to withstand the onslaught of birds when the grains of grain in the countryside dry on us are also good for him through this instrument. And when it comes to cultural festivals other than duty, we see these instruments when the Village Festival comes into being. Now even in the villages where such devices are disappearing, the DJ, Teen mar, Orchestra has come up with a similar program and these folk songs, which are the word of the village, have become extinct. We all have a responsibility to make sure that these instruments are kept in the division for a few years and then displayed. However, let us know about the awards that LR Krishnababu, who is also a kanjera instrumentalist, has received for his performances such as the folk songs he has sung with his bands.

\section{METHODOLOGY:}

Methodology is the main purpose of the design of the kanjera material and Design folk song as it is being done and how these designs will be presented to the future. As part of our team to study, Krishna Babu, the elder son of father Pentayya, who nurtured the family by telling such Burrakathas learned from his father, taught him life lessons of many hardships from an early age with two younger sisters. Lotla Pentayya (late) family has a background of telling Burrakathas in temples in these professionally related families over time. Happiness Comes Very Happiness Fellow Interviewed Our team with me was making a documentary and collaborating with you on the certificates L.R. Krishnababu received on how to present their folk songs designs to future generations. As long as I was doing study on the folk Study of the Kanjera Instrument and its Significance it made us very happy to see the environment around me.

Andhra Jaalari Nruthyam (In Telugu Name): What Fishermen Dance tells us is that the lifestyle of a fisherman is as good as it gets. Jaalari dance is very important and is a testament to their culture of fishing, the fisherman wakes up early in the morning, catches up with his timekeepers, catches them, prepares the boat, and informs them of any difficulties before going hunting into the sea. The pleasure he enjoys fishing in the middle of the sea conveys his idea of his food in that place where he works, given his family circumstances. The way the boat drives their senses in this way 


\section{DOI: $10.17148 / I A R J S E T .2021 .8849$}

is repairing the Net. This is known as Andhra Fisherman dance. What's impressive about this dance is the music and the acting, but the unspoken action of the actor. L.R. Krishnababu is best known for such dances. Many performances on this dance Many stage shows were held in different places Thana America ,Srikakulam to Visakhapatnam, Vijayawada, Eluru, Rajahmundry ,Guntur, Nellore, Kadapa, Anantapur, Chittoor etc. Many state performances were held and Also honored by many Trained in this way, he cannot give up his dream and continue his life if he believes in art. That being said not one but two where every government is motivating the people by bringing their concert team to fellow people where welfare schemes. Here are some of the welfare schemes that have been done so far. Let us tell you the details.

Welfare Society L. R. Krishnababu Chaitanya Kalabharati: Arogya shree (in Telugu name) programs by Chaitanya Kalabharati, Jangareddy Gudem village under the auspices of the Department of Information and Civil Affairs, Government of Andhra Pradesh, He has been making a living for the arts by doing a lot of work in bringing public and private projects to the masses in folk dance through an organization called, He has also acted as a speaker for the speeches of politicians and has attracted a lot of people through his stories. Chaitanya Bharathi has played many roles in folk performances as well as social drama through the art world. Not to mention that he has written many performances in the field of folk art, social dramas, Burrakathas, Kola tam groups and songs for revolutionaries. So far, over No of 6,000 above performances have been given. Some of these magicians, Vasikarana, and show are very good at dreaming of riding a bike blindfolded. In other words, folk songs are being taught to students for free by the Prajanatya Mandali (in Telugu name). Let's give his presentations in his own words. Akshara Deeksha (in Telugu name), HIV, Small savings company, Health security, Nutrition Food, Under the auspices of the United Nations, the Groundwater Conservation Party has conducted a number of awareness programs on conservation. He thus performed a number of folk dances and songs for various welfare programs, giving a variety of performances without a break, as if he had been infected with a sore throat. The dilemma of what to do without leaving this field of art then my Children, Family, looked at the photos of the cells that were near him and put the burden on God and remained the same, It was at that time that the idea of making amounts came up and many artists made a living by making memento symbols. Thus for three years he was dumbfounded and had to push my family to take photos in my case also, borrowing wherever possible is the most difficult part of raising a family. Krishna babu said : God has really saved my family system by starting performing songs, folk poems, folk dances and concerts on the art form that gives me a voice again. After that Awards Rewards Many awards have been received by government and private charities in appreciation of his performances. YS Rajasekhara Reddy Memorial Award, Distinguished Service Ratna, Kalaratna, Best Service Kalaratna, NTR Memorial Award. The village news brought him a lot of fame

Kanjera Awards: 2019 Folk Father Award in APJ Abdul Kalam Celebration by Shikara Art Theater, Hyderabad. 2017 Ugadi (in Telugu name ) Awards Janma Bhoomi, Our village Folk Art Krishna Babu received the contribution at the hands of Sri Nara Chandra Babu Naidu at the state Ugadi Award. (The then Ex Chief Minister Chandrababu Naidu was honored for his contribution to the Janma Bhoomi program initiated by the then Chief Minister Shri. Nara Chandra Babu Naidu from 1998 to 2017 by participating in the Janma Bhoomi Exhibition voluntarily and performing 175 exhibitions all over Andhra Pradesh. 2017 May Citizen Honor Folk Art Gem Citizens award. 2017 West Godavari BC,ST, SC, Minorities members honored ( The songs he sang went to every village and explained in the form of folk songs any welfare schemes of the government how to eradicate literacy how to protect the environment how to take homeland schemes to the people He was honored Celebrities). 2003 The title of Kala seva Ratna award was bestowed on L.R. Krishnababu (The reason for receiving this award is that as part of the 1998 to 2000 Voluntary Janma Bhoomi program, folk songs on these Janma Bhoomi schemes were given folk songs performances in 120 villages in Andhra Pradesh for which the then Chief Minister Shri Nara Chandra Babu Naidu handed over a check. 2018 Bharat Book of Record Certificate Jangareddy Gudem, West Godavari District, Andhra Pradesh Certificates are awarded on behalf of the Bharat Book of Record under India Association for performing the folk song Folk Song on the concept of Saving Environment on a daily basis. 2014 State Folk Artists Welfare Society, World Folklore Day August 22 Folklore researcher Shiromani praising your artistic talent The Nedunuri Gangadharam award was presented. (His songs are in the heart of the Telugu people Singing country, his folk art is dedicated to folk art, are indebted to the Telugu nation for making so many in the Andhra Pradesh region and making your own reputation.) Government of Andhra Pradesh Department of Language and Cultural Affairs under the auspices of Sri Navya Kala Natya Mandali United World Record 5 hours 50 minutes 50 seconds art exhibition as part of which he participated and registered his name. 2017 Siri Muvva Social Service and art Association presented the "Folk Brahma award "on the occasion of the 20th anniversary of Potti Sri ramulu Abhyudaya Vedika, Andhra Pradesh. 
Vol. 8, Issue 8, August 2021

\section{DOI: $10.17148 /$ IARJSET.2021.8849 \\ REVIEW OF LITERATURE:}

Evolution and assessment of South Asian folk Music: A study of social religious perspective Ruksana Karim Wrote (2015) : What this author is saying is that countries like South Asia have different cultures, different folk music, art culture Of these, however, the kanjara instrument, which is the most complete of the folk music, is one of the oldest in South Asia where the culture dates back to 5,000 years ago. So this is a testament to the folk art culture of the countries of the world, especially in Asia. ${ }^{1}$ Folk Music of Andhra Pradesh, Indian Musical Society, Vinjamuri Seetha Devi Wrote (2010): Folk Music of Andhra Pradesh on literature which deals with the characteristic s of the folk songs of Andhra Pradesh, with a brief description of the various types of folk songs in Andhra, the field of folk music, and also as a producer of folk music in all India radio for more than twenty years vinjamuru brought out the music of the folk songs and it s textual content in relation to their society and culture in an admirable way. ${ }^{2}$ The electric strings of south India: A case study of electric Guitar in south Indian classical Music, Wrote (2016): What this author is saying, however, is that music is made by electronic devices. Ancient folk poems, works, or sciences have all been shown to be instrumental to your musical instrument, such as the kanjara tambourine guitar drum. These musical instruments can be used as instruments for music such as the kanjara tambura guitar drum and veena. Musical instruments also translate folk songs into electronics and electrical technology to adapt to changing circumstances. ${ }^{3}$ The Development of the Kanjira in south India, Tradition and Renewal : N. Scott Robinson Wrote (2013) : The kanjira is a small tambourine used in conjunction with other Carnatic percussion instruments in South Indian art music. There have been no comprehensive studies of its history, performance practice, organ logical development, and the ethnography of its performers until now. Only a few articles published in India have detailed the organ logical issues regarding the kanjira's membrane, shell, and its performers. ${ }^{4}$ Bharata in his Natyasastra book wrote (chapter no 33): Kanjera various Name in: a study of the history of the kanjera was to sort out the entire various frame drums used in India. This was necessary because the kanjera itself appears to have previously been a rather limited topic for research and publication To begin with; the term for the instrument has many Romanizations, some from North India and others from South India. North Indian terms include khanjeri (Urdu) and khenjir and khanjari (Hindi), while South Indian terms include kanjira and ganjira (Tamil), kanjira (Malayalam) and kanjera (Telugu), and khanjira (Kannada), among others. Some researchers assert that These generally mean kanjira, these are commonly known as kanjera but in terms of research the words vary a lot. S.A.K. Durga claimed, the music that comes through this healing entertains the folk songs and conveys the meaning of the feeling while entertaining the man with excitement."The forerunner of the Frame Drum Khanjari can be said. ${ }^{5}$ The Trinity's music for vocal and instrumental performance in the twentieth-century, Sangeetha Sampradaya Wrote (2011): However, Tirtha says that Carnatic music has been a tradition in North India since the 13th century. This type of music has been referred to as the Golden Age but from the 17th century to the 20th century Stated . Music is a folk culture. Folk instrumental music. The performance of these. This is evidenced by the fact that these three composers, known as Tyagaraja, Muthuswamy, Dikshitar and Shyamashastri, who were musicians of the Trinity of Carnatic in the 18th century, performed traditional folk concerts. ${ }^{6}$ music - the sounds of flint knapping, Wrote (2020): However, the author says that the role of wood is very important in the creation of the hi pin, how to teach music through this auction can start music education by listening to beautiful music. Much has been made of this violin education as evidenced by the fact that musical instruments are on display for us. ${ }^{7}$ First Croatian Tambura and other instruments Factory Wrote (2020): Musical instruments became increasingly in demand in the mid-1990s as the number of musical instruments increased by thousands of products and the business grew through their use of instruments and their prestige increased as their skills gained recognition after World War II. ${ }^{8}$ Scientific Problems in the construction of musical instrument, Sangeeta Nataka Academi Wrote 2020: This musical instrument produces sound through instruments while the drink increases while you cry while the tone increases and decreases to the other side sound is satisfactorily listening to this kanjara instrument which stands out in this order at the level of folk art. ${ }^{9}$ Recent research into oldwan hominin activities at Kanjera south ,western kenya Wrote (2006): This paper shows that the excavations at e kanjara South in Kenya, which is being carried out by the Archaeologists are still struggling to gather enough evidence before reaching the final conclusions. These artefacts in this area are folk poem folk song folk dance folk musical instruments What remains are the music that gives a lot of excitement to the lives of the people without causing any harm to the environment as evidenced by this Oldowan site. Taphonomic analyses suggest that the archaeological layers were formed at least partially by hominine activity. by Archaeological Study suggest the They have identified a variety of artefacts and the evolution that has taken place since then is a testament to the fact that their habitats have 


\title{
International Advanced Research Journal in Science, Engineering and Technology
}

\author{
Vol. 8, Issue 8, August 2021
}

\section{DOI: $10.17148 /$ IARJSET.2021.8849}

evolved into a variety of artefacts. ${ }^{10}$ American anthropologist physical anthropology origins: what new discovers Reveal about the emergency of our species and its possible future: Wrote (2006): Their analysis that human evolution is much shorter and more straightforward than they once thought is a saying that has been around for many years is nothing new but an old word that the ancestors portrayed as making an instrument for their pleasure merriment for the define of the rebellious defence. Thus through archaeological evidence Isaac and Hijack have been mentioned since the last decade 31 for the organization with the American anthropologist (1979) judgement and has been a key leader in the actual fieldwork. ${ }^{11}$ The social context of Irish folk instruments Wrote (1995): the use of instruments in folk music or traditional music is the socio-cultural and social history of the community as well as the role of this folk music in presenting the basic political and economic experience in the form of his folk instruments that are fundamental to their religious and economic event. ${ }^{12}$ Folk Instruments of Belgium Wrote (2003): Children playing musical instruments excite the student's brain by giving the students who are in the primary class student stage the joy of listening to the sound of this instrument. When listening to such music, the children's style is fun and immersed in the music so that they can have a lot of satisfaction with the work, so these instruments say that their brain is active, giving them a lot of joy if you tell folk songs or poems with your voice. ${ }^{14}$ Improved Folk Instruments as a Factor of Holistic System of Academic Musical and Instrumental Culture of Our Time: Wrote (2018): folk Instruments Tell the extent to which they contribute to children as well as the historical process of music analytically illustrates the aesthetic, a cultural, theoretical and historical methods of a culture. He noted that the unit's acoustic academic musical and instrumental play a vital role in presenting these art forms in detail as a comprehensive artistic cultural and musical phenomenon. ${ }^{15}$

\section{CONCLUSION:}

Once upon a time there was a huge popularity of folk artists and it is declining day by day. Based on this, many such families are not able to give up this art and continue their life only on livelihood. Not one, not two. Many families are losing their livelihood. The popularity of the arts in our country means that such people who initially depended on agriculture for their livelihood have a secondary approach to the arts. These instruments are useful for the society by making fellow people happy by playing fellow e music in which kanjera instrument folk songs are very relaxed and humane. Their hope is that the importance of such instruments will be conveyed to their own future. What these artists want is to introduce this single dream into the future in book form. And there is no harm in doing so through these. There is no gain or loss in learning this dream.

\section{REFERENCES:}

1. Ruksana karim. Evolution and assessment of South Asian folk Music: A study of social religious perspective, British journal of arts and Humanities 2(3) 2020, p.61.

2. Vinjamuri Seetha Devi, Folk Music of Andhra Pradesh, Indian musical society, 2010, p.132.

3. Andre Fludd, The electric strings of south India: A case study of electric Guitar in south Indian classical Music, 2016 , p.1.

4. N. Scott Robinson, Tradition and Renewal: The Development of the Kanjira in south India, 2013, p.1.

5. S.A.K. Durga, Bharata in his Natyasastra, Book [in Chapter 33].

6. The Trinity's music for vocal and instrumental performance in the twentieth-century, Sangeetha Sampradaya ,Book 2011 in p.130

7. Heather N. Smith, Book Rock music - the sounds of flint knapping, Book 2020 in p.22.

8. Jadan Jeic, First Croatian Tambura and other instruments Factory Terezija Kovacic,2017,p.12

9. S. Ramanatham, Scientific Problems in the construction of musical instrument, Sangeeta Nataka Academic Wrote 1970 : Book 1970 in

p.79

10. L.C. Bishop, Recent research into oldwan hominin activities at Kanjera south ,western Kenya Book 2006 in p.1

11. Richard E. Leakey and Roger Lewin, American anthropologist physical anthropology: origins: what new discovers Reveal about the emergency of our species and its possible future, 1977 in p.264

12. Thomas F. Johnston ,The social context of Irish folk instruments, IRASM(26) 1995 in p.35

13. Ferd. J. Dehen, Folk Instruments of Belgium: part1, 2003in p.07

14. Dallas Cline, folk Making simple folk instruments for children:vol66issue 1980 in p.07

15. Alla Dmitrivna Chernoivanenko, Improved Folk Instruments as a Factor of Holistic System of Academic Musical and Instrumental Culture of Our Time: 2018in p.07

16. Flow chart and Construction of Kanjera (9 x 7 x 2 Inches).

17. 2017 Ugadi Awards Folk song Kanjera Folk Artisan. 